\title{
Prevalence and Associated Risk Factors of Hypertension in a Rural Community of Western Nepal: A Cross Sectional Study
}

\author{
Kafle RC, Sharma D, Paudel N, Sapkota S, Alurkar VM \\ Department of Medicine, Manipal College of Medical Sciences, Pokhara, Nepal
}

\section{DOI Name}

http://dx.doi.org/10.3126/jaim.v7i1.19577

\section{Keywords}

Diabetes mellitus; Hypertension; Prevalence; Risk factors.

\section{Citation}

Kafle RC, Sharma D, Paudel N, Sapkota S, Alurkar VM. Prevalence and Associated Risk Factors of Hypertension in a Rural Community of Western Nepal: A Cross Sectional Study. Journal of Advances in Internal Medicine 2018;07(01):11-16.

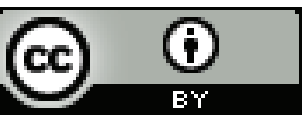

This work is licensed under a Creative Commons Attribution 3.0 Unported License.

\begin{abstract}
Background and aim: Hypertension is a major risk factor for cardiovascular disease. Hypertension evolved as a major public problem in urban populations of many countries including Nepal, but little is known about its prevalence and risk factors in rural areas. The objective of our study was to assess the prevalence of and risk factors associated with hypertension.

Methods: A community-based cross-sectional survey was carried out in November 2017 in a four days health camp where peoples from ward number eight of Suklagandaki municipality of Tanahu district were called for screening of diabetes mellitus. No prior notice was given to the population about screening of hypertension. We screened total of 568 participants. Demographics, anthropometry and two independent blood pressure (BP) readings were taken. The data was analyzed using descriptive and inferential statistics using SPSS version 18.0
\end{abstract}

Results: A total of 568 individuals were interviewed and taken complete $\mathrm{BP}$, weight and height measurements. More than $1 / 3$ rd (36.26\%) of the respondents were in age group 18 - 39 years with mean age $47.49 \pm 16.61$. Nearly, $60 \%$ of the respondents were female. Whilst $17.3 \%$ were smokers and $20 \%$ reported drinking alcohol. Overall prevalence of hypertension was $41.55 \%$ and this was significantly associated with age, gender, education, size of family, smoking habits, intake of alcohol, presence of diabetes mellitus.

Conclusion: The prevalence of hypertension was found to be high and it has become a important public health issue even in rural part of Nepal. Community screening program, timely detection, lifestyle modification, treatment and prevention are all important to deal with life-threatening complications and chronic debilitating morbidity.

\section{INTRODUCTION}

Cardiovascular disease (CVD) is the leading cause of death worldwide. The incidence of CVD is increasing in both developed and developing countries. Cardiovascular disease is emerging as a major problem in low and middle income countries. The less prevalent non-communicable diseases have taken the place of more prevalent infectious diseases and malnutrition even in developing countries. In 2013 there were $>54$ million deaths globally and $32 \%$ of these deaths, or 17 million were attributable to CVD. The majority of these CVD deaths were attributable to either ischemic heart disease (IHD) or cerebrovascular disease. ${ }^{1}$ Bradshaw and colleagues reported that hypertension, strokes and ischemic heart disease are amongst the most common NCDs causing many premature adult deaths in South Africa. ${ }^{2}$ Cardiovascular disease has emerged as a major burden of disease in developing countries as well. ${ }^{3-5}$

\footnotetext{
* Corresponding author

Ram Chandra Kafle

Manipal College of Medical Sciences

Pulbari-11, Pokhara, Nepal

drkafle30@gmail.com.
} 
Different epidemiological studies have increasingly revealed the risk factors for CVD in developing countries. These include, amongst others, obesity, alcohol intake, smoking, hypertension and diabetes mellitus. ${ }^{6-8}$ Hypertension remains the most common life threatening risk factor for CVD in developing countries. ${ }^{9}$ The prevalence of hypertension varies from $5 \%$ to $50 \%$ in sub-Saharan countries whilst it ranges between $19 \%$ and $30 \%$ in economically developed countries. ${ }^{2}$

The prevalence of NCDs is increasing in Nepal. In 2008, nearly $50 \%$ of total deaths in Nepal were estimated to be due to NCDs, and CVD accounted for $25 \%$ of these deaths. Hypertension, one of the major risk factors for CVD, was estimated to be present in $27.8 \%$ of Nepalese adults aged 25 years and above. According to recent estimates from the World Health Organization, Nepal reported the second highest proportion of hypertensive people(27.3\%) after Afghanistan(29\%). ${ }^{10}$ The largest of these studies, a community-based screening for CVD risk factors in eastern Nepal, showed a hypertension prevalence of $33.9 \%$ among adults 20 years of age and above. ${ }^{11}$

The objective of the study was to estimate the prevalence of hypertension and its associated risk factors in rural area of $\mathrm{Ne}$ pal.

\section{Materials and methods}

A cross-sectional community-based study was carried out from $1^{\text {st }}$ November - 30 $0^{\text {th }}$ December 2017 in a four days health camp where peoples from ward number eight of Suklagandaki municipality of Tanahu district were called for screening of Diabetes Mellitus. No prior notice was given to the population about screening of hypertension. The sample populations were $\geq 18$ years of age. We screened total of 568 participants.

Data were collected by face-to-face interview, clinical examinations and anthropometric measurements,. Interview was conducted using semi-structured questionnaire. Their blood pressure was measured using calibrated aneroid sphygmomanometer with appropriate cuff size in standard method in the camp. The blood pressure was measured two times on upper arm in sitting position and the average was recorded. Hypertension was defined as systolic blood pressure $\geq 140 \mathrm{mmHg}$ and/or diastolic blood pressure $\geq 90 \mathrm{mmHg}$. Those who were diagnosed previously and taking antihypertensive medication were also defined as hypertensive. The diagnosis and classification of hypertension was done according to the JNC-7 report. Waist hip circumference was also measured using inch tape and waist hip ratio was calculated. WHO criteria was used to classify waist hip ratio. Individuals diagnosed with any mental disorder or pregnant women were excluded from the study. Participants who were willing to participate and available at the time of data collection were included in the study.
Data analysis was planned based on the objectives of the study. Data was compiled, edited, coded, classified and tabulated. It was done to reduce, organize and give meaning to the data by through descriptive and inferential statistics using SPSS package 18 version. In descriptive statistics (frequency, percentage, mean and SD) and inferential statistics (Chi-square test). Approval to conduct the study was taken from incharge of $\mathrm{MCH}$ clinic, DPHO who had organized the camp. Individual consent was taken from the respondents after explaining the purpose of the study prior to the data collection. Privacy and confidentiality of all respondents was maintained.

\section{Results}

A total of 568 individuals were interviewed during study period and all responded with complete information.

Table 1: Socio-demographic characteristics of the responden ts

$$
n=568
$$

\begin{tabular}{|c|c|c|}
\hline Socio-demographic characteristics & Frequency(f) & $\begin{array}{l}\text { Percent- } \\
\text { age (\%) }\end{array}$ \\
\hline \multicolumn{3}{|l|}{ Age (years) } \\
\hline $18-39$ & 206 & 36.26 \\
\hline $40-59$ & 196 & 34.5 \\
\hline$\geq 60$ & 166 & 29.22 \\
\hline Mean \pm SD & $47.49 \pm 16.61$ & \\
\hline \multicolumn{3}{|l|}{ Gender } \\
\hline Female & 340 & 59.9 \\
\hline Male & 228 & 40.1 \\
\hline \multicolumn{3}{|l|}{ Marital status } \\
\hline Married & 500 & 88.0 \\
\hline Others & 68 & 12.0 \\
\hline \multicolumn{3}{|l|}{ Religion } \\
\hline Hindu & 552 & 97.2 \\
\hline Other & 16 & 2.8 \\
\hline \multicolumn{3}{|l|}{ Education of the respondents } \\
\hline Literate & 374 & 65.8 \\
\hline Illiterate & 194 & 34.2 \\
\hline \multicolumn{3}{|l|}{ Education of the spouse $(n=530)$} \\
\hline Literate & 334 & 63.01 \\
\hline Illiterate & 196 & 36.98 \\
\hline \multicolumn{3}{|l|}{ Occupation of respondents } \\
\hline Unskilled & 376 & 66.2 \\
\hline Semiskilled & 116 & 20.4 \\
\hline Skilled & 76 & 13.4 \\
\hline \multicolumn{3}{|l|}{ Occupation of the spouse $(n=530)$} \\
\hline Unskilled & 312 & 58.8 \\
\hline Semiskilled & 182 & 34.3 \\
\hline Skilled & 36 & 6.8 \\
\hline
\end{tabular}

More than $1 / 3$ rd (36.3\%) of the respondents were in age group 18- 39 years with mean \pm SD; $47.49 \pm 16.61$. Nearly, $60 \%$ of the respondents were female. Less than $2 / 3$ rd (65.8\%) of the respondents were literate. Among 530 respondents, $63.1 \%$ of the respondents spouse were literate. About $2 / 3^{\text {rd }}(66.2 \%)$ of the respondents were unskilled worker. 
Table 2: Dietary and other practices of the respondents $\mathrm{n}=\mathbf{5 6 8}$

\begin{tabular}{|c|c|c|}
\hline Sample characteristics & $\begin{array}{l}\text { Frequency } \\
\text { (f) }\end{array}$ & $\begin{array}{l}\text { Percentage } \\
\text { (\%) }\end{array}$ \\
\hline \multicolumn{3}{|l|}{ Dietary pattern } \\
\hline Vegetarian & 84 & 14.8 \\
\hline Non-vegetarian & 484 & 85.2 \\
\hline \multicolumn{3}{|l|}{ Smoking status } \\
\hline Yes & 98 & 17.3 \\
\hline No & 470 & 82.7 \\
\hline \multicolumn{3}{|l|}{ Alcohol use } \\
\hline Current & 112 & 19.7 \\
\hline Never & 418 & 73.6 \\
\hline Previous & 38 & 6.7 \\
\hline \multicolumn{3}{|c|}{$\begin{array}{l}\text { Amount of alcohol use per week } \\
\text { (units) }(n=112)\end{array}$} \\
\hline $10-50$ & 42 & 37.5 \\
\hline $51-100$ & 40 & 35.7 \\
\hline$\geq 100$ & 30 & 26.8 \\
\hline \multicolumn{3}{|c|}{ Fruit consumption per week (days) } \\
\hline $1-3$ & 394 & 69.4 \\
\hline $4-7$ & 174 & 30.6 \\
\hline \multicolumn{3}{|l|}{ Vegetable use per week (days) } \\
\hline $1-3$ & 276 & 48.6 \\
\hline $4-7$ & 292 & 51.4 \\
\hline \multicolumn{3}{|l|}{ Life style } \\
\hline Sedentary & 254 & 44.7 \\
\hline Non-sedentary & 314 & 55.3 \\
\hline \multicolumn{3}{|l|}{ Previous history of HTN } \\
\hline Yes & 146 & 25.7 \\
\hline No & 422 & 74.3 \\
\hline \multicolumn{3}{|c|}{ Taking medicine for HTN $(n=146)$} \\
\hline Yes & 110 & 75.3 \\
\hline No & 36 & 24.7 \\
\hline \multicolumn{3}{|l|}{ HTN under control $(n=110)$} \\
\hline Yes & 62 & 56.4 \\
\hline No & 48 & 43.6 \\
\hline
\end{tabular}

Among 568 respondents, more than 4/5th respondents were non-vegetarian. Seventeen percentage (17.3\%) of the respondents were smoker. Nearly $20 \%$ of the respondents were alcohol consumer and $6.7 \%$ of the respondents had stopped drinking alcohol. Previous history of hypertension among respondents were 25.7\%. Among 146 respondents, 110(75\%) were taking medication. Out of 110 respondents taking medi- cation, $43.6 \%$ of the respondents B.P was not controlled with medication.

Table 3 : Sample characteristics of the respondents $\mathrm{n}=\mathbf{5 6 8}$

\begin{tabular}{|c|c|c|}
\hline Sample characteristics & $\begin{array}{l}\text { Frequency } \\
\text { (f) }\end{array}$ & $\begin{array}{c}\text { Percentage } \\
\text { (\%) }\end{array}$ \\
\hline \multicolumn{3}{|l|}{ Name of medicine $(n=110)$} \\
\hline Amlodipine & 92 & 83.6 \\
\hline Losartan & 14 & 12.7 \\
\hline Ayurvedic & 4 & 3.6 \\
\hline $\begin{array}{l}\text { Reason for not taking medicine ( } \mathrm{n} \\
=36 \text { ) }\end{array}$ & 16 & 44.4 \\
\hline Medicine need to be taken regularly & 8 & 22.2 \\
\hline Fear of side effect & 12 & 33.3 \\
\hline \multicolumn{3}{|l|}{$\begin{array}{l}\text { Wish to control with lifestyle } \\
\text { change }\end{array}$} \\
\hline \multicolumn{3}{|l|}{$\begin{array}{l}\text { Frequency of measuring BP at } \\
\text { hospital (month) }(n=146)\end{array}$} \\
\hline$<3$ & 114 & 78.1 \\
\hline$\geq 3$ & 32 & 21.9 \\
\hline \multicolumn{3}{|l|}{ Family history of HTN } \\
\hline Yes & 188 & 33.1 \\
\hline No & 380 & 66.9 \\
\hline \multicolumn{3}{|l|}{ Present $h / o$ of diabetes mellitus } \\
\hline Yes & 130 & 22.9 \\
\hline No & 382 & 67.3 \\
\hline Don't know & 56 & 9.9 \\
\hline \multicolumn{3}{|l|}{ Time of recent BP measurement } \\
\hline$\leq 6$ & 100 & 17.6 \\
\hline \multicolumn{3}{|l|}{$>6$} \\
\hline \multicolumn{3}{|l|}{ Presence of any other illness } \\
\hline Yes & 130 & 22.9 \\
\hline No & 382 & 67.3 \\
\hline Don't know & 56 & 9.9 \\
\hline \multicolumn{3}{|l|}{ BMI } \\
\hline Normal (18.5 - 24.5) & 250 & 44.0 \\
\hline Overweight (25 - 29.9) & 214 & 37.7 \\
\hline Obesity (Class I and II) & 104 & 18.3 \\
\hline \multicolumn{3}{|l|}{ Waist hip ratio } \\
\hline Normal & 150 & 26.4 \\
\hline High & 418 & 73.6 \\
\hline \multicolumn{3}{|l|}{ Current status of BP } \\
\hline Normal & 410 & 72.2 \\
\hline High & 158 & 27.8 \\
\hline \multicolumn{3}{|l|}{ Prevalence of HTN ( $n=236$ ) } \\
\hline New case & 90 & 15.8 \\
\hline Old case & 146 & 25.7 \\
\hline
\end{tabular}

Among 146 respondents, $24.7 \%$ were not taking medication for hypertension. Forty four percentage of the respondents replied that reason for not taking medicine is it need to be taken regularly. Nearly $1 / 3 \mathrm{rd}$ (33.1\%) of the respondents were having family history of hypertension and $22.9 \%$ have history of diabetes mellitus. Current status of BP was measured and revealed that nearly $28 \%$ of the respondents were having high blood pressure. Among 568 respondents, prevalence of hyper- 
tension is $236(41.5 \%)$. The percentage of newly diagnosed cases were $90(15.8 \%)$ and $146(25.7 \%)$ were previously diagnosed cases.

Table 2: Association of hypertensive status with socio-demographic characteristics $\mathrm{n}=\mathbf{5 6 8}$

\begin{tabular}{|c|c|c|c|c|}
\hline \multirow{2}{*}{$\begin{array}{c}\text { Sample } \\
\text { characteristics }\end{array}$} & \multicolumn{2}{|c|}{ Hypertensive status } & \multirow[b]{2}{*}{ COR } & \multirow[b]{2}{*}{$\mathrm{p}$ value } \\
\hline & $\begin{array}{l}\text { Normal } \\
(\%)\end{array}$ & High (\%) & & \\
\hline \multicolumn{5}{|l|}{ Age (in years) } \\
\hline $18-39$ & $172(83.5)$ & $34(16.5)$ & Ref. & \\
\hline $40-59$ & $122(62.2)$ & $74(37.8)$ & $3.068(1.584-5.945)$ & 0.003 \\
\hline$\geq 60$ & $116(69.9)$ & $50(30.1)$ & $2.181(1.082-4.393)$ & \\
\hline \multicolumn{5}{|l|}{ Gender } \\
\hline Male & $148(64.9)$ & $80(35.1)$ & $1.816(1.074-3.070)$ & 0.025 \\
\hline Female & $262(77.1)$ & $78(22.9)$ & Ref. & \\
\hline \multicolumn{5}{|l|}{$\begin{array}{l}\text { Education of } \\
\text { respondents }\end{array}$} \\
\hline Illiterate & $124(63.9)$ & $70(36.1)$ & $1.835(1.075-3.132)$ & 0.025 \\
\hline Literate & $286(76.5)$ & $88(23.5)$ & Ref. & \\
\hline \multicolumn{5}{|l|}{ Size of family } \\
\hline$\leq 4$ & $146(70.9)$ & $60(29.1)$ & $0.575(0.282-1.175)$ & 0.029 \\
\hline $5-7$ & $208(78.2)$ & $58(21.8)$ & $0.390(0.193-0.791)$ & \\
\hline$>7$ & $56(58.3)$ & $40(41.7)$ & Ref. & \\
\hline \multicolumn{5}{|l|}{ Smoking } \\
\hline Yes & $354(75.3)$ & $116(24.7)$ & $(1.208-4.335)$ & \\
\hline No & & & Ref. & \\
\hline \multicolumn{5}{|l|}{ Alcohol use } \\
\hline Yes & $62(55.4)$ & $50(44.6)$ & $2.858(1.537-5.313)$ & \\
\hline Previous & $22(57.9)$ & $16(42.1)$ & $2.577(0.979-6.783)$ & 0.001 \\
\hline Never & $326(78.0)$ & $92(22.0)$ & Ref. & \\
\hline \multicolumn{5}{|l|}{$\begin{array}{l}\text { Present his- } \\
\text { tory of DM }\end{array}$} \\
\hline Yes & $52(55.3)$ & $42(44.7)$ & $2.493(1.305-4.760)$ & 0.006 \\
\hline No & $358(75.5)$ & $116(24.5)$ & Ref. & \\
\hline
\end{tabular}

Table 2 revealed that with reference to age group 18 to 39 years, age 40 to 59 years and $>=60$ years were more likely to be hypertensive with COR; 3.068 (1.584 - 5.945) and 2.181(1.082 - 4.393) respectively. Male gender were more likely to be hypertensive than female gender with COR; 1.816(1.074 - 3.070). Size of the family members were significantly associated to hypertension with COR; 0.390 (0.193 - 0.791). Smokers were at higher risk for hypertension than non smoker with COR; 2.289(1.208 - 4.335). Alcohol consumption was found to have the positive association to high blood pressure than alcohol non users with $2.858(1.537-5.313)$ while no such relation was seen with previous alcohol user with $2.577(0.979$ - 6.783). Present history of DM is also significantly associated with hypertension as COR is 2.493(1.305 - 4.760). However, we couldn't establish association with other variables like marital status, religion, occupation, dietary pattern, life style, family history of HTN, presence of any other illness, BMI, waist hip ratio.

\section{Discussion}

The present study showed that overall prevalence of hypertension was $41.5 \%$ which is similar to the study by Ntuli ST et al $(41 \%){ }^{12}$ In a study done in Thiruvananthapuram city in Kerala, the overall prevalence in adult population of more than $40 \mathrm{yrs}$ was $54.5 \% .{ }^{13}$ The prevalence of hypertension was $37.8 \%$ among residents of rural communities of Nigeria. ${ }^{14}$ Whereas lower prevalence was obtained in studies by Koju R et al $(28.9 \%)^{15}$ and Satheesh BC et al (18.5\%). ${ }^{16}$ The prevalence of hypertension in China in adult population of 35 to 74 years was $27.2 \%$ in a recent study. ${ }^{17}$ The reported prevalence of hypertension varied around the world, with the lowest prevalence in rural India (3.4\% in men and $6.8 \%$ in women) and the highest prevalence in Poland (68.9\% in men and $72.5 \%$ in women). ${ }^{4}$

Out of total 236 (41.5\%) hypertensive cases, 15.8\% were unaware of their status of hypertension which is similar to the study from Afganistan. ${ }^{18}$ Among, 110 hypertensive participants taking medication, 43.6\% participants had uncontrolled hypertension comparable to the study done in USA where $53.5 \%$ had uncontrolled hypertension ${ }^{19}$ and Joint National Committee (JNC) sixth report which believed that only about half of the patients who are diagnosed as hypertensive are adequately controlled. ${ }^{20}$

The current study observed that the number of hypertension is increasing with the advancing age, the hypertension is $19.5 \%$ among < 30 years' age, $37.8 \%$ in 30 - 49 years and $30.1 \%$ in $\geq 50$ years. The study revealed the significant association between age groups and hypertension with $\mathrm{p}$ value 0.003 which is consistent to the various studies where significant association was established at $p$ value $<0.001 .{ }^{21-24}$ Male respondents had higher odds of being hypertensive compared to females (OR = $1.816 ; 95 \% \mathrm{Cl}=1.074-3.070$ ) which is similar to the study from North West Tanzania, ${ }^{22}$ Rural Nepal, ${ }^{25}$ and central Nepal. ${ }^{26}$ Literacy level of the respondent was also found to be significantly associated with hypertension which is in line with the study by Ntuli ST, ${ }^{12}$ Dhungana RR, ${ }^{21}$ Mosha NR, ${ }^{22}$ and Saeed KMI. ${ }^{23}$

Nearly $1 / 5$ th of the participants reported current use of alcohol which is analogous to the study by Ntuli ST. ${ }^{12}$ Alcohol consumption was found to have the positive association to high blood pressure than alcohol non users with 2.858(1.537 - 5.313). Similar findings was obtained in other studies by Dhungana RR, ${ }^{21}$ Mosha NR, ${ }^{22}$ Abebe SM. ${ }^{27}$ While no significant association was found in the study by Sam T. Ntuli. ${ }^{12}$ Recent study confirm that smoking status were significantly associated with high blood pressure similar result was obtained in a study from Afganistan, ${ }^{23}$ Nairobi Kenya, ${ }^{24}$ Rural Nepal, ${ }^{25}$ Kathmandu valley, ${ }^{28}$ Vietnam. ${ }^{29}$ While no significant association was found in the study conducted by Koju et al. ${ }^{15}$ 
Kafle RC, et al. Prevalence and Associated Risk Factors of Hypertension in Western Nepal| Original Article

Presence of diabetes among study participants increased the odds of being hypertensive by 2.493 times compared to nondiabetic participants similar to the study from Kathmandu ${ }^{21}$ and Afghanistan. ${ }^{23}$ Shrestha et al found that hypertension was less common with normal plasma glucose than in those with diabetes (18.8\% vs. $36.7 \%) .{ }^{30}$

A significantly higher number of individuals were overweight and obese i.e. prevalence of being overweight and obese was $37.7 \%$ and $18.3 \%$ respectively ${ }^{31}$ which is in accordance to the results from Uttar Pradhesh. Nearly $3 / 4^{\text {th }}(73.6 \%)$ of the respondents had waist-hip ratio equal to or more than cut-off ( 0.9 for males and 0.85 for females) which is higher than the study conducted by Olack B where overall prevalence of abdominal obesity was $54.6 \%{ }^{24}$

Earlier studies suggested that a high BMI and waist hip ratio contributes to hypertension. ${ }^{21-23,32-34}$ Whereas present study do not revealed any significant association with hypertension which is similar to the study from South Africa. ${ }^{12}$ This may partly be attributed to the declining use of dietary salt, exercise, fruit consumption, vegetable use.

\section{Conclusion}

This study showed that the hypertension is not only concern of urban population but also important issue in rural areas. This trend is similar worldwide. Since many people B.P were not controlled with medication, some were newly diagnosed, unaware of their disease and its life threatening complications. Community screening program, timely detection, lifestyle modification, treatment and prevention are all important to deal with life-threatening complications and chronic debilitating morbidity.

\section{Acknowledgment}

We are very grateful to incharge of $\mathrm{MCH}$ clinic, all the staff working in the camp, community leaders and respondents who participated in the study giving their valuable time.

\section{References}

1. GBD 2013 Mortality and Causes of Death Collaborators. Global, regional, and national age-sex specific all-cause and cause-specific mortality for 240 causes of death, 1990-2013: a systematic analysis for the Global Burden of Disease Study 2013. Lancet. 2015;385:117-71.

2. Bradshaw D, Nannan N, Groenewald P, et al. Provincial mortality in South Africa, 2000--priority-setting for now and a benchmark for the future. S Afr Med J. 2005;95(7):496-503.

3. Mathers CD, Loncar D (2006) Projections of Global Mor- tality and Burden of Disease from 2002 to 2030. PLoS Med 3(11): e442. https://doi.org/10.1371/journal. pmed.0030442.

4. Kearney PM, Whelton M, Reynolds K, Muntner P, Whelton PK, He J. Global burden of hypertension: Analysis of worldwide data. Lancet. 2005;365:217-23.

5. Alberts M, Urdal P, Steyn K, Stensvold I, Tverdal A, Nel JH, et al. Prevalence of cardiovascular diseases and associated risk factors in a rural black population of South Africa. Eur J Cardiovasc Prev Rehabil. 2005;12(4):347-54.

6. Lopez AD, Mathers CD, Eszati M, Jamison DT, Murray CJL. Global burden of disease and risk factors. Washington, DC: World Bank; 2006. http://dx.doi. org/10.1596/978-08213-6262-4.

7. Steyn K, Sliwa K, Hawken S, Commerford P, Onen C, Damasceno $A$, et al. Risk factors associated with myocardial infarction in Africa: The interheart Africa study. Circulation. 2005;112:3554-61.

8. O’Donnell MJ, Xavier D, Liu L, Zhang H, Chin SL, RaoMelacini $P$ et al. Risk factors for ischaemic and intracerebral haemorrhagic stroke in 22 countries (the interstroke study): A casecontrol study. Lancet. 2010;376:112-123. doi: 10.1016/S0140-6736(10)60834-3. Epub 2010 Jun 17.

9. Connor $M$, Rheeder $\mathrm{P}$, Bryer A, Meredith $M$, Beukes $M$, Dubb $A$, et al. The South African stroke risk in general practice study. S Afr Med J. 2005;95:334-9.

10. World Health Organization. Global health observatory. Geneva. http://apps.who.int/gho/data/?theme=main\# accessed 22 November 2017.

11. Sharma SK, Ghimire A, Radhakrishnan J, Thapa L, Shrestha NR, Paudel N, et al. Prevalence of hypertension, obesity, diabetes, and metabolic syndrome in Nepal. Int J Hypertens. 2011;2011:821971. doi: 10.4061/2011/821971. Epub 2011 Apr 19.

12. Ntuli ST, Maimela E, Alberts M, Choma S, Dikotope S. Prevalence and associated risk factors of hypertension amongst adults in a rural community of Limpopo Province, South Africa. Afr J Prm Health Care Fam Med. 2015;7(1): 847.

13. Zachariah MG, Thankappan KR, Alex SC, Sarma PS, Vasan RS. Prevalence, correlates, awareness, treatment and control of hypertension in a middle-aged urban population in Kerala. Indian Heart J. 2003 May-Jun; 55:245-51.

14. Isara AR, Okundia PO. The burden of hypertension and diabetes mellitus in rural communities in southern Nigeria. 
Pan African Medical Journal. 2015; 20:103. doi: 10.11604/ pamj.2015.20.103.5619.

15. Koju R, Manandhar K, Gurung R, Pant P, Bedi TRS. Prevalence of Hypertension in Semi-Urban area of Nepal.NHJ November 2010;7(1):35-9.

16. Satheesh BC, Mohammad Iliyas CM. Prevalence of hypertension in a rural community of North Kerala, India: a cross sectional study. Int J Community Med Public Health. 2017 Feb;4(2):528-31

17. Gu D, Reynolds K, Wu X, Chen J, Duan X, Muntner P, et al. Interasia Collaborative Group. The International Collaborative Study of Cardiovascular Disease in ASIA. Prevalence Awareness, treatment and control of hypertension in China. Hypertension 2002 Dec;40(6):920-7.

18. Saeed KMI. Prevalence and Associated Factors of High Blood Pressure in Urban Setting of Kandahar City in Afghanistan in 2015, Jundishapur J Helath Sci. 2017 ;9(3):e59990. doi: 10.5812/jjhs.59990.

19. Vital Signs: Awareness and Treatment of Uncontrolled Hypertension Among Adults - United States. MMWR. 2012 ; 61:1-7.

20. JNC 6th report on prevention, detection, evaluation, and treatment of high blood pressure. Arch Int Med. 1997;157: 2413-46.

21. Dhungana RR, Pandey AR, Bista B, Joshi S, Devkota S. Prevalence and Associated Factors of Hypertension: A Community-Based Cross-Sectional Study in Municipalities of Kathmandu, Nepal. Int J Hypertens. 2016;2016:1656938. doi: 10.1155/2016/1656938. Epub 2016 May 12.

22. Mosha NR, Mahande M, JumaA, Mboyal, PeckR, etal. Prevalence, awareness and factors associated with hypertension in North West Tanzania. Global Health Action 2017;10(1), 1321279, DOI: 10.1080/16549716.2017.1321279

23. Saeed KMI. Prevalence of hypertension and associated factors in Jalalabad City, Nangarhar Province, Afghanistan. Central Asian Journal of Global Health 2015;4(1). DOI 10.5195/cajgh.2015.134

24. Olack B, Wabwire-Mangen F, Smeeth L, Montgomery JM, Kiwanuka N, Breiman RF. Risk factors of hypertension among adults aged 35-64 years living in an urban slum Nairobi, Kenya. BMC Public Health (2015) 15:1251. doi 10.1186/s12889-015-2610-8
25. Chataut J, Khanal K, Manandhar K. Prevalence and Associated Factors of Hypertension among Adults in Rural Nepal: A Community Based Study. Kathmandu Univ Med J 2015;52(4):346-50.

26. Shrestha A. Dietary factors associated with Hypertension in Nepal. Published Thesis 2012. University of Washington.

27. Abebe SM, Berhane Y, Worku A, Getachew A. Prevalence and Associated Factors of Hypertension: A Crossectional Community Based Study in Northwest Ethiopia. PLoS ONE 2015; 10(4): e0125210. https://doi.org/10.1371/journal. pone. 0125210 .

28. Gautam A, Khan GA, Timilsina S. Prevalence of Risk Factors of Hypertension in Nepalese Population. Int Arch BioMed Clin Res. 2017;3(1):44-46. DOI:10.21276/iabcr.2017.3.1.12

29. Thuy AB, Blizzard L, Schmidt MD, Luc PH, Granger RH, Dwyer $\mathrm{T}$. The association between smoking and hypertension in a population-based sample of Vietnamese men. J Hyper 2010; 28: 245-50.

30. Shrestha UK, Singh DL, Bhattarai MD. The prevalence of hypertension and diabetes defined by fasting and $2-\mathrm{h}$ plasma glucose criteria in urban Nepal, Diabetic Medicine 2006;23(10):1130-35.

31. Jindal R, Jindal N, Dass A. Prevalence of hypertension and its association with various risk factors-a survey in Uttar Pradesh. International Journal of Contemporary Medical Research 2016;3(11):3410-12.

32. Dhungana RR, Devkota S, Khanal MK, Gurung Y, Giri RK, Parajuli RK, et al. Prevalence of cardiovascular health risk behaviors in a remote rural community of Sindhuli district, Nepal. BMC Cardiovasc Disord. 2014 Jul 28;14:92. doi: 10.1186/1471-2261-14-92.

33. Vaidhya A, Pathak RP, Pandey MR. Prevalence of hypertension in Nepalese community triples in 25 years: a repeat cross-sectional study in rural Kathmandu. Indian Heart J. 2012 Mar; 64(2): 128-131. doi: 10.1016/S00194832(12)60045-5

34. Foulds HJ, Bredin SS, Warburton DE. The relationship between hypertension and obesity across different ethnicities. J Hypertens. 2012;30(2):359-67. doi: 10.1097/ HJH.0b013e32834f0b86. 